\title{
Extractive Phase Vanishing \\ Reactions with Dichloromethane, \\ Perfluorohexanes and \\ Dibromoethane: Slow Addition in \\ a Test Tube
}

Dennis P. Curran* and Stefan Werner

Department of Chemistry, University of Pittsburgh, Pittsburgh, PA 15260 USA

curran@pitt.edu

\section{Supporting Information}

\section{GC-Analysis:}

The analysis of the composition of solvent mixtures was performed on an Agilent 6850 Series GC System with an HP-1 Methyl Siloxane column (Agilent 19091Z-413E, Capillary 30.0 m x $320 \mu \mathrm{m}$ x 0.25 $\mu \mathrm{m})$. The temperature was maintained at $30^{\circ} \mathrm{C}$ for $3 \mathrm{~min}$ before heating to $150^{\circ} \mathrm{C}$ with a rate of $5^{\circ} \mathrm{C} / \mathrm{min}$, a helium flow of $2 \mathrm{~mL} / \mathrm{min}$ and 8.68 PSI was applied. Biphenyl was used as internal standard and trifluoromethylbenzene (BTF) was used as solvent.

Retention times: $1.8 \mathrm{~min}$ (FC-72), $2.1 \mathrm{~min}$ (DCM), 3.9 (BTF), $5.8 \mathrm{~min}$ (DBE), 21.4 min (biphenyl).

\section{Determination of partition coefficients:}

Mixtures of $1 \mathrm{~mL}$ DCM and $1 \mathrm{~mL}$ FC-72, $1 \mathrm{~mL} \mathrm{DBE}$ and $1 \mathrm{~mL} \mathrm{FC-72,} \mathrm{or} 1 \mathrm{~mL}$ DCM, $1 \mathrm{~mL}$ DBE and $2 \mathrm{~mL}$ FC-72, were shaken vigorously for $5 \mathrm{~min}$. A sample of each phase was dissolved in BTF and injected to the $\mathrm{GC}$ for analysis.

\section{Preparation of the triphasic system with vanishing of the top phase:}

To a test tube (inner diameter $12 \mathrm{~mm}$ ) with a small stirring bar was added $2 \mathrm{~mL}$ DBE. This was covered with $1.5 \mathrm{~mL}$ FC-72. After $2 \mathrm{~min}, 1.5 \mathrm{~mL}$ DCM was carefully added to form the upper phase. The dye was added to the corresponding solvent before the preparation of the three phases. The system was stirred for $2.5 \mathrm{~d}$. 


\section{Preparation of the triphasic system with vanishing of the bottom phase:}

To a test tube (inner diameter $12 \mathrm{~mm}$ ) with a small stirring bar was added $0.5 \mathrm{~mL}$ DBE. This was covered with $1.5 \mathrm{~mL}$ FC-72. After $2 \mathrm{~min}, 3.2 \mathrm{~mL}$ DCM was carefully added to form the upper phase. The dye was added to the DCM before the preparation of the three phases. The system was stirred for $2.5 \mathrm{~d}$.

\section{Preparation of the triphasic system with vanishing of the top phase, starting with different} densities of the top phase:

To a test tube (inner diameter $12 \mathrm{~mm}$ ) with a small stirring bar was added $2 \mathrm{~mL}$ DBE. This was covered with $1.5 \mathrm{~mL} \mathrm{FC-72.} \mathrm{After} 2 \mathrm{~min}, 1.5 \mathrm{~mL}$ of a solvent mixture DCM/DBE was carefully added to form the upper phase. It is extremely difficult to form the triphasic system when the top phase and the middle phase have similar densities and in those cases the dye was added to the top phase after successful formation of the triphasic system. The system was stirred very gently until the top phase vanished. Under an identical stirring speed this took $2 \mathrm{~d}$ with a density of the top phase of $\mathrm{d}=1.6 \mathrm{~g} / \mathrm{mL}, 5 \mathrm{~d}$ for $\mathrm{d}=1.5 \mathrm{~g} / \mathrm{mL}, 7 \mathrm{~d}$ for $\mathrm{d}$ $=1.4 \mathrm{~g} / \mathrm{mL}$ and $14 \mathrm{~d}$ for $\mathrm{d}=1.33 \mathrm{~g} / \mathrm{mL}$ (only DCM). Under normal stirring the last experiment $(\mathrm{d}=1.33$ $\mathrm{g} / \mathrm{mL}$ ) took only $2.5 \mathrm{~d}$, but no significant difference could be observed between the first two experiments (d $=1.6$ and $1.5 \mathrm{~g} / \mathrm{mL}$ ).

Stock solutions for solvent mixtures of DCM/DBE with the corresponding densities were obtained by mixing 12.6 mL DCM and 7.4 mL DBE $(\mathrm{d}=1.6 \mathrm{~g} / \mathrm{mL}), 15.1 \mathrm{~mL} \mathrm{DCM}$ and $4.9 \mathrm{~mL}$ DBE $(\mathrm{d}=1.5 \mathrm{~g} / \mathrm{mL})$, 17.6 $\mathrm{mL} \mathrm{DCM}$ and $2.4 \mathrm{~mL} \mathrm{DBE}(\mathrm{d}=1.4 \mathrm{~g} / \mathrm{mL})$. These densities were calculated according to ref 4 in the paper. 